\title{
Prospective Evaluation of Patients with Chronic Dyspnea in a Pulmonary Out-Patient Clinic Using an Algorithm
}

\author{
Göğ̈is Hastalıklarn Polikliniğinde Kronik Dispneli Hastalamn Bir \\ Algoritma Işı̆̆ında Prospektif Değerlendirilmesi
}

\author{
Serpil Göçmen Öcal ${ }^{1}$, Mine Durusu Tanrı̈ver², Öznur Akkoca Yıldız³ ${ }^{3}$ Arzu Topeli İskit², Lütfi Çöplü ${ }^{1}$ \\ ${ }^{1}$ Department of Chest Diseases, Faculty of Medicine, Hacettepe University, Ankara \\ ${ }^{2}$ Department of Internal Medicine, Faculty of Medicine, Hacettepe University, Ankara \\ ${ }^{3}$ Department of Chest Diseases, Faculty of Medicine, Ankara University, Ankara
}

\section{ABSTRACT}

Objective: The aim of this study was to evaluate the causes of chronic dyspnea in patients of an outpatient clinic prospectively and to implement an efficient diagnostic approach.

Methods: A prospective study was performed with an algorithm for chronic dyspnea. After the patients were evaluated by the history and physical examination, blood tests, chest X-ray (CXR), and spirometry were performed in all cases. The methacholine inhalation challenge test was proposed as a diagnostic test in situations where clinical asthma is suspected and spirometric findings are non-obstructive. All patients whose basic tests were normal, high resolution computed tomography (HRCT), computed tomography (CT), pulmonary angiography, and transthoracic echocardiography (TTE) were performed as second step tests.

Results: As basic tests were non-diagnostic in 58 patients, second step tests were performed. Twelve patients with high clinical probability of asthma were positive on the methacholine inhalation challenge test and responded to asthma treatment. With this algorithmic approach, a final diagnosis was reached in $90 \%$ of the patients. The most frequent diagnoses were asthma (27\%), chronic obstructive pulmonary disease (COPD) (17\%), bronchiectasis (13\%), and heart failure (10\%).

Conclusion: As a result of this comprehensive protocol, most causes of chronic dyspnea were found to be airway and heart diseases. We would suggest that CXR and spirometry can be performed as first step tests. We consider that when the results of the basic tests are normal, both TTE and HRCT are very useful tests.

Keywords: Asthma, bronchiectasis, COPD, dyspnea, heart failure

\section{ÖZET}

Amaç: Poliklinikte kronik dispne nedenlerinin prospektif değerlendirilmesi ve etkili tanısal yaklaşım oluşturulması amaçlanmıştır.

Yöntemler: Kronik dispne için bir algoritma kullanılarak prospektif çalışma yapıldı. Tüm hastalar anamnez ve fizik muayeneyle değerlendirildikten sonra kan testleri istendi, spirometri yapildı ve akciğer filmi çekildi. Klinik olarak astım şüphesi olan ancak spirometride non-obstrüktif olan hastalarda metakolin provoakasyon testi yapıldı. Birinci basamak testler normal olan hastalarda yüksek rezolüsyonlu bilgisayar tomografi (YRBT), bilgisayar tomografi (BT), pulmoner anjiyografi ve transtorasik ekokardiyografiyle (TTE) ikinci basamak testler yapildı.

Bulgular: Birinci basamak testlerle tanı konulamayan kronik dispneli hastaların 58'ine ikinci basamak testler uygulandı. Klinik olarak astım şüphesi olan 12 hastada metakolin provoakasyon testi pozitifti ve astım tedavisine başarılı yanıt verdi. Bizim kullandığımız algoritma ile hastaların yaklaşık \%90'ına tanı konuldu. Kronik dispnenin en sık nedenleri astım (\%27), kronik obstrüktif akciğer hastalığı (KOAH) (\%17), bronşiektazi (\%13) ve kalp yetmezliği (\%10) olarak izlendi.

Sonuç: Uyguladığımız basamaklı tanısal algoritma sonucu, kronik dispnenin sıklıkla nedeni havayolu ve kalp hastalıkları olarak saptandı. Gögüus hastalıkları polikliniğinde kronik dispneli hastalarda akciğer filmi ve spirometri birinci basamak testler olarak kullanılabilir. Birinci basamak testler normal olduğu zaman, ikinci basamak testler olarak YRBT ve TTE'den yararlanılabilir.

Anahtar Kelimeler: Astım, broşektazi, dispne, kalp yetmezliği, $\mathrm{KOAH}$

Received date / Geliş tarihi: 23.01.2013 Accepted date / Kabul tarihi: 15.03.2013

Address for correspondence / Yazışma adresi: Serpil Göçmen Öcal, Department of Chest Diseases, Faculty of Medicine, Hacettepe University, Ankara, Turkey;

E-mail: drserpilgocmen@yahoo.com

(C) Copyright 2013 Turkish Respiratory Society (TRS) • C) Telif hakkı 2013 Türkiye Solunum Araştırmaları Derneği (TÜSAD)

Solunum 2013;15(2):94-99 • DOI: 10.5152/solunum.2013.017

Available online at www.solunum.org.tr/dergi • Makalelerin tam metinlerine www.solunum.org.tr/dergi adresinden ulaşabilirsiniz. 


\section{INTRODUCTION}

In clinical practice, chronic dyspnea is probably the most common respiratory complaint. The cause of this symptom is determined more accurately by using objective test results combined with clinical impressions compared with clinical impression alone (1). For this reason, some diseases known to be the cause of chronic dyspnea are so similar to each other in their signs and symptoms clinically that physicians may not decide to order an additional test. While much has been written regarding chronic dyspnea, data supporting its clinical evaluation are scarce. Historically, a number of approaches have been taken for the diagnosis of patients with this complaint, including specific diagnostic tests according to patient characteristics (1) and cardiopulmonary exercise testing in patients with unexplained dyspnea by routine evaluation $(2,3)$. However, an efficient and simple diagnostic approach has not yet been found.

The aim of the present study was two-fold: to prospectively evaluate the causes of chronic dyspnea in patients in an out-patient clinic and to implement an efficient and simple diagnostic approach.

\section{METHODS}

\section{Patients}

We defined "dyspnea" as a subjective experience of breathing discomfort that consists of qualitatively distinct sensations that vary in intensity, and "chronic dyspnea" as dyspnea lasting longer than one month. One hundred consecutive adult patients with chronic dyspnea were seen in the pulmonary subspecialty clinic at a University Hospital. The study was approved by the research ethics committee, and all subjects gave written informed consent.

\section{Patient evaluation}

At the initial evaluation, a subjective assessment of dyspnea severity was recorded for each patient using the Medical Research Council (MRC) and Baseline Dyspnea Index (BDI) scale. A questionnaire including the age, gender, weight, height, duration of dyspnea, aggravating factors, other accompanying symptoms (such as cough, sputum, hemoptysis, chest pain, gastroesophageal reflux-related symptoms), a history of cigarette smoking and additional diseases were determined. Blood tests -including complete blood count (CBC), metabolic profile (MP), and thyroid function tests (TFT), chest X-ray (CXR), and spirometry with bronchodilator reversibility if appropriate, were performed in all cases. When the results of the basic tests were normal, the following tests were conducted to confirm diagnosis. The Methacholine inhalation challenge test was proposed as a diagnostic test in situations where clinical asthma was suspected and spirometric findings were non-obstructive. In all patients whose basic tests were normal high resolution computed tomography (HRCT), computed tomography (CT) pulmonary angiography, and transthoracic echocardiography (TTE) were ordered.

\section{Identification of Diagnostic Subgroups}

For a disease to be accepted as the reason for the patient's dyspnea, the following criteria were met.

Asthma: A history of episodic wheeze or breathlessness during or following exercise, in cold air, or aggravated by aerosols or sprays, suggested asthma. A diagnosis of asthma was considered only when patients showed reversible airflow obstruction or airway hyperresponsiveness $\left(\mathrm{PC}_{20} \leq 8 \mathrm{mg} / \mathrm{mL}\right.$ methacholine) and reported dyspnea resolution or satisfactory improvement following specific treatment (4).

Chronic obstructive pulmonary disease (COPD): A diagnosis of COPD was given to smokers who had $\mathrm{FEV}_{1} / \mathrm{FVC}<70 \%$ in spirometry in addition to chronic dyspnea, cough and/or sputum production (5).

Bronchiectasis: Bronchiectasis was suggested by a history of expectoration of purulent sputum. The diagnosis was confirmed by compatible features on CXR or HRCT (6).

Small airway disease (SAD): Small airway disease was diagnosed when forced expiratory flow between $25 \%$ to $75 \%$ $\left(\mathrm{FEF}_{25-75} \%\right)$ was $<65 \%$ of predicted value in the presence of a normal $\mathrm{FEV}_{1}, \mathrm{FVC}_{1} \mathrm{FEV}_{1} / \mathrm{FVC}$ and after exclusion of all other causes of dyspnea (7).

Interstitial lung disease (ILD): Initially suggested by clinical features and radiographic appearance, the diagnosis of ILD was confirmed by HRCT scanning.

Heart failure: The diagnosis of heart failure was made on the criteria of the European Society of Cardiology (ESC); i.e. symptoms suggestive of heart failure and objective evidence of cardiac (systolic and/or diastolic) ventricular dysfunction at rest assessed by TTE. Patients with heart failure were further classified as having 'systolic', 'isolated diastolic', or 'right-sided heart failure'. For systolic heart failure, patients had to have an left ventricular ejection fraction (LVEF) $\leq 45 \%$ in combination with symptoms indicative of heart failure (such as orthopnea, fatigue, nocturnal dyspnea, peripheral edema, nocturia more than twice a night, or any combination of these symptoms). For isolated diastolic heart failure, patients had to have echocardiographic diastolic abnormalities in combination with indicative symptoms and signs (such as peripheral or pulmonary fluid retention or raised jugular venous pressure) of heart failure or indicative symptoms and echocardiographic left ventricular hypertrophy, atrial fibrillation, or anginal complaints. Patients who had moderate to severe mitral or aortic stenosis/insufficiency were diagnosed as valvular disease. Pulmonary artery (PA) systolic pressure was estimated from the peak tricuspid regurgitation jet velocities according to the following equation: PA systolic pressure $=4(\mathrm{~V})^{2} \mathrm{~mm} \mathrm{Hg}$, where $\mathrm{V}$ is the peak velocity (in meters per second) of a tricuspid valve regurgitant jet. A diagnosis of pulmonary arterial hypertension (PAH) was made definite with mean PA pressure of $>25 \mathrm{mmHg}$ based on the findings of TTE (8).

Gastroesophageal reflux disease (GERD): A clinical probability of GERD was suggested by a history of heartburn, dysphagia, or acid regurgitation or an association between dyspnea and posture or meals. In the absence of these features, esophageal 24-hour $\mathrm{pH}$ monitoring was carried out. Spirometry, TTE, 
Table 1. Characteristics of patients studied

\begin{tabular}{lc}
\hline \hline Characteristics & \\
\hline Subjects (n) & 100 \\
Females (\%) & 56 \\
Age (years) & $51.14 \pm 13.89(18-82)$ \\
BMI (kg/m $\left.{ }^{2}\right)$ & $28.35 \pm 5.72(15.20-46.09)$ \\
Duration of dyspnea (months) & $53.38 \pm 48(1-480)$ \\
Aggravating factors (Yes) (\%) & 59 \\
Smokers (Yes) (\%) & $24.79 \pm 16.04(1.00-50.00)$ \\
Cigarette pack years & $75.54 \pm 20.12(31-128)$ \\
FEV $(\%)$ & $81.19 \pm 18.59(34-128)$ \\
FVC (\%) & $76.46 \pm 10.88(36-100)$ \\
FEV $/$ FVC & $2.57 \pm 0.98(1-5)$ \\
MRC dyspnea index & $7.05 \pm 2.68(1-12)$ \\
BDI & 45 \\
Obesity & 83 \\
\hline
\end{tabular}

Data presented as $n$, median, median (range), and mean \pm SD.

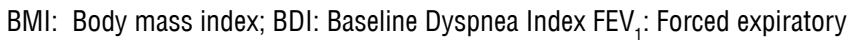
volume in one second; \% pred, percentage of the predicted value, FVC: Forced vital capacity, MRC: Medical Research,

HRCT, and CT pulmonary angiography was performed in all patients with GERD to exclude other causes of dyspnea (9).

Anemia: Anemia is typically defined as a hemoglobin level of less than $12 \mathrm{gr} / \mathrm{dL}$, however it was considered as a cause of dyspnea when the hemoglobin falls below $<8 \mathrm{gr} / \mathrm{dL}(10,11)$.

Diabetes mellitus (DM): Diabetes was diagnosed if the fasting plasma glucose was higher than $126 \mathrm{mg} / \mathrm{dL}$. When symptoms of marked hyperglycemia including polydipsia, polyuria, weight loss, nausea, vomiting, and abdominal pain were found, arterial blood gases, and urinalysis (ketones) were performed to demonstrate diabetic ketoacidosis (DKA) (12).

\section{RESULTS}

\section{Patient characteristics}

We enrolled 100 consecutive patients with chronic dyspnea over four months. Because 8 patients did not complete their diagnostic tests, our final study group comprised of 92 patients. Their clinical characteristics are summarized in Table 1.

The most common respiratory symptoms that accompanied dyspnea were cough, sputum and wheezing $(78 \%, 65 \%$, and $37 \%$, respectively). Frequently seen comorbid diseases were hypertension, diabetes mellitus, atherosclerotic cardiovascular disease and connective tissue disease $(16 \%, 9 \%, 7 \%$, and $7 \%$, respectively).

Seven patients had a hemoglobin level between 8-12 g/dL. There was an elevation in fasting glucose level in 4 patients but they had no symptoms of DKA. Three patients had increased blood urea nitrogen levels. Only 2 patients had elevated liver transaminases. One of them had chronic liver disease and pleural effusion, and her dyspnea resolved completely after diuretic therapy. The other had connective tissue disease and ILD. While 3 patients had their TSH levels elevated with normal T3, T4subclinical hypothyroidism-, only 1 patient with hypothyroidism had used an excess amount of levothyroxine and had elevated levels of T3 and T4. The abnormal findings on CXR were seen as emphysema in 8 , increasing bronchovascular shadows in 8 , bronchiectasis in 6 , and an interstitial pattern in 2 patients. Although 9 patients had other abnormal findings on CXR, their findings did not explain the chronic dyspnea. As basic tests were non-diagnostic in 58 of the patients, TTE, HRCT, and CT pulmonary angiography were performed.

The above mentioned clinical approach yielded a final diagnosis in $90 \%$ of the patients. The causes of chronic dyspnea and their relative frequencies are shown in Table 2. Dyspnea resulted from respiratory diseases in $76 \%$ and heart diseases in $10 \%$ of the patients. The 3 major diagnoses -asthma, COPD, and bronchiectasis- accounted for 57 of 92 (62\%) cases. Eight of 9 patients with diabetes had an airway and/or cardiovascular disease. Twelve of 17 patients with suspected asthma had asthma as demonstrated by the bronchoprovocation test (BPT). All these 12 patients responded to specific asthma therapy in a month. The frequency with which a test was diagnostic is listed in Table 3.

\section{DISCUSSION}

So far, there have been no studies to our knowledge that focus on how an algorithm can be used to evaluate patients with chronic dyspnea. In the present study, an algorithm for the investigation and management of chronic dyspnea was evaluated in a large unselected group of patients (Figure 1). There is little in the medical literature with which to compare our results. Pratter et al. (1) prospectively evaluated patients with chronic dyspnea using only the specific diagnostic test of the suspected disease but did not use an algorithm. These authors reported that dyspnea resulted from respiratory diseases in $75 \%$ and heart diseases in $10 \%$ of patients in a pulmonary disease clinic. Similar to these results, we also found that this symptom resulted from respiratory diseases in $76 \%$ and heart diseases in $10 \%$ of patients. On the other hand, a number of authors investigated the role of cardiopulmonary exercise testing in the diagnosis of unexplained dyspnea by routine evaluation $(2,3,11)$. This patient population differs from ours owing to the fact that they specifically excluded patients in whom the history, physical examination, CXR, or spirometry adequately explained the symptoms.

In the present study, diagnostic values of blood tests, which are so far not routinely used for differential diagnosis of dyspnea, were also evaluated to clarify the cause of chronic dyspnea. Karnani et al. (11) reported that profound anemia is an unusual but important cause of chronic dyspnea. It was interesting that anemia as a cause of dyspnea was not identified in our study. Also, there was no benefit of glucose measurement to identify the cause of this symptom directly. Therefore, investigation of diabetic ke- 
Table 2. Causes of chronic dyspnea in order of decreasing frequency

\begin{tabular}{|c|c|c|c|}
\hline Diagnosis & Patients (n) & & \\
\hline \multirow[t]{6}{*}{ Asthma } & 27 & History of aggravating factors & 21 \\
\hline & & Positive smoking history & 6 \\
\hline & & Obstructive deficit on spirometry & 14 \\
\hline & & Reversibility to B2 agonist & 14 \\
\hline & & Airway hyperresponsiveness & 12 \\
\hline & & $\begin{array}{l}\text { Improvement in dyspnea } \\
\text { with therapy }\end{array}$ & 1 \\
\hline \multirow[t]{4}{*}{ COPD } & 17 & History of aggravating factors & 3 \\
\hline & & Positive smoking history & 17 \\
\hline & & Obstructive deficit on spirometry & 17 \\
\hline & & Reversibility to B2 agonist & 3 \\
\hline \multirow[t]{6}{*}{ Bronchiectasis } & 13 & History of aggravating factors & 9 \\
\hline & & Obstructive deficit on spirometry & 3 \\
\hline & & Reversibility to $\mathrm{B}_{2}$ agonist & 1 \\
\hline & & Restrictive deficit on spirometry & 5 \\
\hline & & $\begin{array}{l}\text { Abnormal chest radiography } \\
\text { for bronchiectasis }\end{array}$ & 6 \\
\hline & & $\begin{array}{l}\text { Abnormal HRCT for } \\
\text { bronchiectasis }\end{array}$ & 7 \\
\hline \multirow[t]{4}{*}{ Heart diseases } & 10 & History of aggravating factors & 2 \\
\hline & & Systolic dysfunction on TTE & 5 \\
\hline & & Valvular dysfunction on TTE & 3 \\
\hline & & Diastolic dysfunction on TTE & 2 \\
\hline \multirow[t]{3}{*}{ SAD } & 6 & Positive smoking history & 6 \\
\hline & & $\begin{array}{l}\text { Small airway obstruction } \\
\text { on spirometry }\end{array}$ & 6 \\
\hline & & Abnormal HRCT for SAD & 2 \\
\hline \multirow[t]{3}{*}{ ILD } & 3 & Restrictive deficit on spirometry & 1 \\
\hline & & $\begin{array}{l}\text { Abnormal chest radiography } \\
\text { for ILD }\end{array}$ & 2 \\
\hline & & Abnormal HRCT for ILD & 3 \\
\hline \multirow[t]{3}{*}{ PAH } & 3 & $\begin{array}{l}\text { History of connective tissue } \\
\text { disease }\end{array}$ & 2 \\
\hline & & History of chronic hepatic failure & 1 \\
\hline & & Pulmonary hypertension on TTE & 3 \\
\hline \multirow[t]{2}{*}{ GERD } & 3 & GERD-related symptoms & 3 \\
\hline & & $\begin{array}{l}\text { Improvement in dyspnea with } \\
\text { therapy }\end{array}$ & 3 \\
\hline \multirow[t]{3}{*}{ Kyphoscoliosis } & 1 & Typical physical examination & 1 \\
\hline & & $\begin{array}{l}\text { Severe skeletal deformity on } \\
\text { chest radiography }\end{array}$ & 1 \\
\hline & & Restrictive deficit on spirometry & 1 \\
\hline
\end{tabular}

COPD: Chronic obstructive pulmonary disease, GERD: Gastroesophageal lung disease, HRCT: High resolution computed tomography, ILD: Interstitial lung disease, PAH: Pulmonary arterial hypertension, SAD: Small airway disease, TTE: Transthoracis echocardiography
Table 3. Diagnostic yield of non-invasive tests

\begin{tabular}{lccc}
\hline \hline & $\begin{array}{c}\text { No. } \\
\text { Abnormal }\end{array}$ & $\begin{array}{c}\text { No. } \\
\text { Performed }\end{array}$ & $\begin{array}{c}\text { No. } \\
\text { Diagnostic }\end{array}$ \\
\hline Measurement of hemoglobin & 8 & 100 & 0 \\
Measurement of glucose & 4 & 100 & 0 \\
Liver function test & 2 & 100 & 2 \\
Renal function test & 3 & 100 & 0 \\
Thyroid function test & 4 & 100 & 1 \\
Spirometry & 56 & 94 & 37 \\
CXR & 33 & 98 & 8 \\
BPT & 13 & 17 & 12 \\
TTE & 21 & 58 & 13 \\
HRCT & 23 & 58 & 12 \\
CT pulmonary angiography & 0 & 58 & 0 \\
\hline
\end{tabular}

BPT: Bronchoprovocation test, CT: Computed tomography, CXR: Chest x_ray, HRCT: High resolution computed tomography, TTE: Transthoracic echocardiography

toacidosis may be helpful in approaching acute but not chronic dyspnea. We found that causes of chronic dyspnea in patients with DM are often airway and/or heart disease. Renal disease leads to dyspnea via anemia and volume overload. Although a few patients had prerenal azotemia, which can be a result of volume depletion, this condition could not explain their dyspnea in the present study. Patients with chronic liver disease often complain of dyspnea because of hepatopulmonary syndrome, pleural effusion, ILD, and PAH. In this study, only 2 patients had elevated liver function tests $(13,14)$. One with chronic liver disease had a pleural effusion and her symptom resolved completely after diuretic therapy. The other with connective tissue disease had an ILD which explained chronic dyspnea. Hypothyroidism may be associated with respiratory failure that can be caused by a reduction in central respiratory drive, upper airway obstruction, and associated restrictive pulmonary function from pleural effusions or an intrinsic decrease in lung volumes. Hyperthyroidism can present with dyspnea as a major clinical manifestation because of the increase in central respiratory drive associated with thyrotoxicosis. Cardiac dysfunction associated with hyperthyroidism may lead to pulmonary edema in some patients (15). It was found that only one patient with a history of thyroid disease was observed to have hyperthyroidism. Also, subclinical hypothyroidism was found in 3 patients. The effect of subclinical hypothyroidism on several organ systems is well known, whereas the effect on respiratory system is not fully understood (16-18).

As a result, blood tests were used as the first step tests but were not useful diagnostically. We would suggest that the evaluation of such patients should involve careful history taking and examination. We consider that these tests are not indicated but should be reserved for refractory cases.

Spirometry and CXR were used as first step tests. In our study, since COPD and asthma were the cause for half of our 
cases, spirometry was the most useful diagnostic test. Similarly, Pratter et al. (1) showed that COPD and asthma were the cause of dyspnea in 45 percent of their patients. This test is useful in distinguishing obstructive lung diseases from restrictive lung diseases (11). Bronchoprovocation test with methacholine was used when asthma was suspected and spirometry was normal. We do not recommend BPT for routine use since false-positive results can occur in dyspneic patients with COPD, congestive heart failure and bronchiectasis (19). However, BPT is a useful test for evaluation of patients with normal spirometric tests and who are suspected to have asthma.

In clinical practice, CXR is usually performed as part of the initial evaluation of dyspnea. A review by Morgan and Hodge stated that the most useful methods for evaluating dyspnea are the electrocardiogram and CXR (20). However, there are no references in this regard. In a study of hospitalized patients with dsypnea, CXR was helpful in making a diagnosis in $66 \%$ of the patients admitted for other reasons and referred to respiratory physicians for dyspnea (21). As patients with dyspnea at the emergency department were included, most of them might have had acute symptoms. We believe that CXR is a more useful test in the evaluation of acute dyspnea rather than chronic. In the present study, while CXR is abnormal in $24 \%$ of the patients with chronic dyspnea, this test was diagnostic only for $12 \%$ these patients. In contrast, in the above mentioned study, half of patients had the correct diagnosis following a history and physical examination in combination with a CXR (1). Although CXR demonstrated a lower efficiency for diagnosing dyspnea in our study, it may be needed to exclude other diagnoses.

We performed HRCT, CT pulmonary angiography and TTE as second step tests. Even in the presence of a normal CXR, HRCT might demonstrate a significant pulmonary abnormality in patients with chronic dyspnea. Even though HRCT is a more sensitive diagnostic modality than CXR for detecting airway disease-especially SAD- and parenchymal lung diseases (11), previous authors didn't benefit from HRCT in the diagnosis of chronic dyspnea (1-3). It was found that half of patients with bronchiectasis were diagnosed with HRCT. We think that HRCT can be considered in patients with chronic dyspnea when the initial evaluation (clinical assessment, CXR and spirometry) is non-diagnostic or non-revealing. Interestingly, pulmonary thromboembolism was not detected in any patients who underwent second step tests. CT pulmonary angiography may be necessary in patients with PAH on TTE. We showed that TTE was the second useful test after spirometry and offers a useful adjunct to detect etiologies such as heart failure, $\mathrm{PAH}$, valvular disease and pericardial effusion. Twelve percent of our patients had a cardiac cause of dyspnea, which was similar to Pratter and colleagues findings (1).

Using the present protocol, it was found that an underlying cause could be established in more than $90 \%$ of patients with chronic dyspnea. The most common causes included airway and heart diseases. Other causes consist of ILD, pulmonary vascular diseases, GERD, SAD, kyphoscoliosis. Radiological studies of SAD are very popular in recent years. Unfortunately, the relationship between SAD and dyspnea is unknown and further studies are needed. Since anti-reflux therapy resulted in complete resolution of symptoms in all of the patients with GERD, specific diagnostic test was not performed to confirm the diagnosis.

\section{Limitations of the study}

Firstly, cardiopulmonary exercise testing (CPEX) can be extremely useful for investigating dyspnea. It is especially indicated when the exact cause of dyspnea remains unclear despite diagnostic studies. Unfortunately, CPEX was not performed as a third step test in our study. Secondly, different diseases may coexist in the same patient with chronic dyspnea. In our study, the coexistence of diseases remained unrecognized.

\section{CONCLUSION}

This study describes the outcome of a comprehensive simple protocol applied to all patients referred with chronic dyspnea in a pulmonary out-patient clinic. An algorithm was created to evaluate chronic dyspnea specifically for our country (Figure 1) and it yielded a diagnosis in $90 \%$ of the cases. Conducted in an unselected series of patients, our findings support the currently held view that identifying a cause is the best approach. The medical

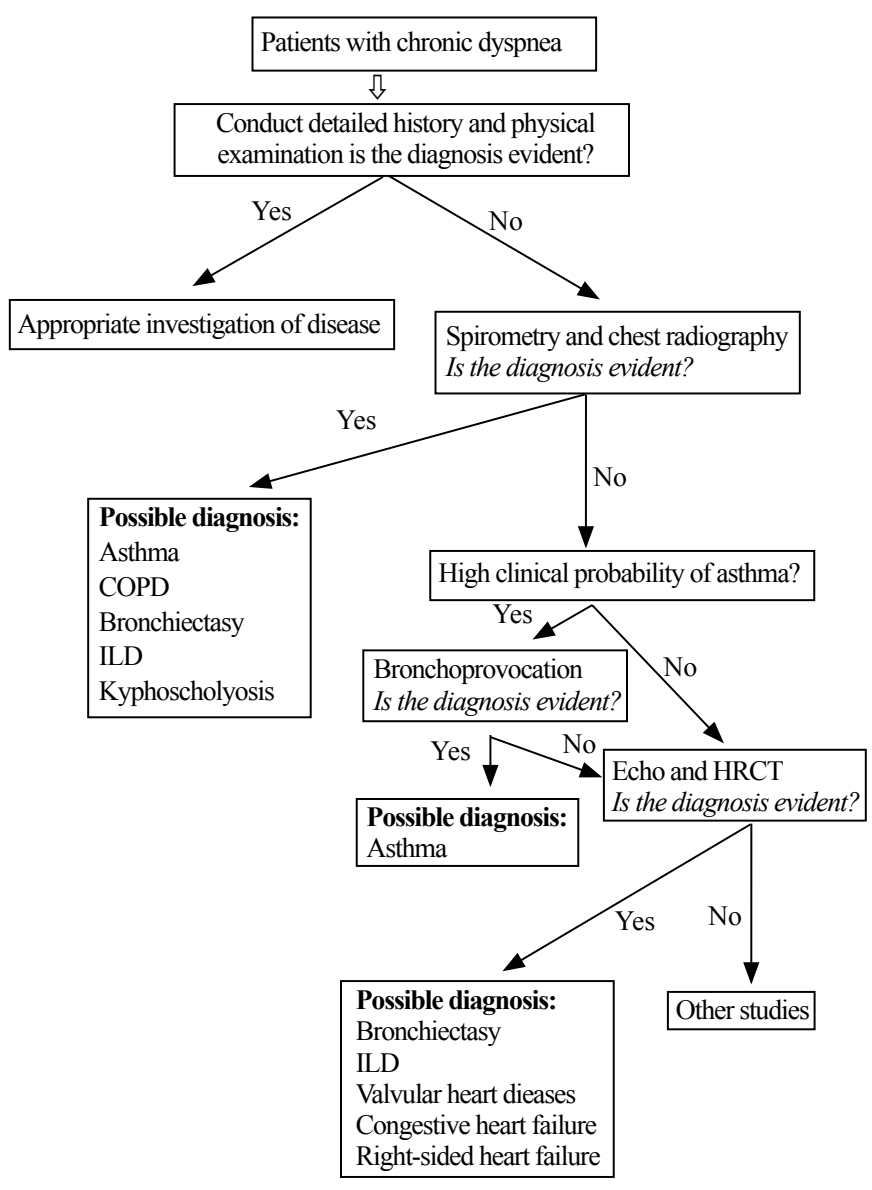

Figure 1. An algorithmic approach to chronic dyspnea. 
history and physical examination are the first and most important steps in the clinical evaluation of chronic dyspnea. Laboratory testing should be ordered as second step using a logical approach to diagnose the most probable cause of chronic dyspnea.

\section{Conflict of Interest}

No conflict of interest was declared by the authors.

Peer-review: Externally peer-reviewed.

\section{Author Contributions}

Concept - S.G.Ö., Ö.A.Y.; Design - S.G.Ö., M.D.T.; Supervision - S.G.Ö., A.T.I.; Funding - S.G.Ö., L.Ç.; Materials - S.G.Ö., M.D.T.; Data Collection and/or Processing - S.G.Ö., O.A.Y.; Analysis and/or Interpretation - S.G.Ö., M.D.T.; Literature Review - S.G.Ö., A.T.İ.; Writing - S.G.O., M.D.T.; Critical Review - A.T.İ., L.Ç.; Other - L.Ç.

\section{Çıkar Çatışması}

Yazarlar herhangi bir çıkar çatışması bildirmemişlerdir.

Hakem değerlendirmesi: Dış bağımsız.

\section{Yazar Katkıları}

Fikir - S.G.Ö., Ö.A.Y.; Tasarım - S.G.Ö., M.D.T.; Denetleme S.G.Ö., A.T.İ.; Kaynaklar - S.G.Ö., L.Ç.; Malzemeler - S.G.Ö., M.D.T.; Veri toplanması ve/veya işlemesi - S.G.O., Ö.A.Y.; Analiz ve/veya yorum - S.G.Ö., M.D.T.; Literatür taraması S.G.Ö., A.T.İ.; Yazıyı yazan - S.G.Ö., M.D.T.; Eleştirel İnceleme - A.T.İ., L.Ç.; Diğer - L.Ç.

\section{REFERENCES}

1. Pratter MR, Curley FJ, Dubois J, Irwin RS. Cause and evaluation of chronic dyspnea in a pulmonary disease clinic. Arch Intern Med 1989; 149: 2277-82. [CrossRef]

2. DePaso WJ, Winterbauer RH, Lusk JA, Dreis DF, Springmeyer SC. Chronic dyspnea unexplained by history, physical examination, chest roentgenogram, and spirometry. Analysis of a seven-year experience. Chest 1991; 100: 1293-9. [CrossRef]

3. Martinez FJ, Stanopoulos I, Acero R, Becker FS, Pickering R, Beamis JF. Graded comprehensive cardiopulmonary exercise testing in the evaluation of dyspnea unexplained by routine evaluation. Chest 1994; 105: 168-74. [CrossRef]
4. Global Initiative for Asthma. Global Strategy For Asthma Management and Prevention. 2008 Update. Publication No. 02-3659:1-116. NHLBI/WHO Workshop Report. Bethesda, National Institutes Of Health, National Heart, Lung And Blood Institute, 2008. Available from http:/ /www.ginasthma.com

5. Global strategy for the diagnosis, management, and prevention of chronic obstructive pulmonary disease: executive summary 2009. Global Initiative for chronic obstructive pulmonary disease (GOLD). Available from http://www.goldcopd.org.

6. Barker AF, Ahmed SY. Bronchiectasis. Fishman AP, Elias JA, Fishman JA, Grippi MA, eds. Fishman's pulmonary diseases and disorders. 4th ed. New York: McGraw-Hill, 2008.p.2183-92.

7. Warren MG. Pulmonary function testing. In: Murray DJ, Nadel J; eds. Textbook of respiratory medicine. 3rd ed. Philadelphia: WB Saunders Company; 2000.p.781-871.

8. Swedberg K, Cleland J, Dargie H, Drexler H, Follath F, Komajda M, et al. Guidelines for the diagnosis and treatment of chronic heart failure: executive summary (update 2005): The Task Force for the Diagnosis and Treatment of Chronic Heart Failure of the European Society of Cardiology. Eur Heart J 2005; 26: 1115-40. [CrossRef]

9. DeVault KR, Castell DO; American College of Gastroenterology. Updated guidelines for the diagnosis and treatment of gastroesophageal reflux disease. Am J Gastroenterol 2005; 100: 190-200. [CrossRef]

10. Selcuk T. Hematolojik hastalıklarda akciğer sorunları. In: Metintaş M (ed). Sistemik hastalıklarda ve özel durumlarda akciğer. Eskişehir: Öz Kağıtçılık Matbaacılık Basım San. Tic. A.S., 2004: 343-67.

11. Karnani NG, Reisfield GM, Wilson GR. Evaluation of chronic dyspnea. Am Fam Physician 2005; 71: 1529-37.

12. American Diabetes Association. Diagnosis classification of diabetes mellitus. Diabetes Care 2006; 29(suppl 1): 43-8.

13. Hervé P, Lebrec D, Brenot F, Simonneau G, Humbert M, Sitbon O, et al. Pulmonary vascular disorders in portal hypertension. Eur Respir J 1998; 11: 1153-66. [CrossRef]

14. Strauss RM, Boyer TD. Hepatic hydrothorax. Semin Liver Dis 1997; 17: 227-32. [CrossRef]

15. Brüssel T, Matthay MA, Chernow B. Pulmonary manifestations of endocrine and metabolic disorders. Clin Chest Med 1989; 10: 64553.

16. Col NF, Sarks MI, Daniels GH. Subclinical thyroid disease: Clinical applications. JAMA 2004; 291: 239-43. [CrossRef]

17. Cooper DS.Clinical practice. Subclinical hypothyroidism. N Engl J Med 2001; 345: 260-5. [CrossRef]

18. Çakmak G, Saler T, Sağlam Z, Yenigün M, Demir T. Spirometry in patients with clinical and subclinical hypothyroidism. Tüberküloz ve Toraks Dergisi 2007; 55: 266-70.

19. Cockcroft DV. Bronchoprovocation methods: direct challenges. Clin Rev Allergy Immunol 2003; 24: 19-26. [CrossRef]

20. Morgan WC, Hodge HL. Diagnostic evaluation of dyspnea. Am Fam Physician 1998; 57: 711-6.

21. Mukhopadhyay A, Lim TK. A prospective audit of referrals for breathlessness in patients hospitalized for other reasons. Singapore Med J 2005; 46: 21-4. 